\title{
Peranan Kepolisian Resor Tebing Tinggi Dalam Penegakan Hukum Terhadap Tindak Pidana Ujaran Kebencian Di Media Sosial
}

\section{The Role of the Highest Resort Tebing Tinggi Police in Law Enforcement Against the Hate in Criminal Actions}

\author{
Renal Eldinata Samosir, Taufik Siregar, \& Rizkan Zulyadi \\ Program Studi Magister Ilmu Hukum, Universitas Medan Area, Indonesia \\ Diterima: 04 Juni 2021 Direview: 04 Juni 2021; Disetujui: 20 September 2021 \\ *Coresponding Email: renal@gmail.com
}

\begin{abstract}
Abstrak
Kehadiran teknologi informasi yang demikian canggih telah memberikan nuansa baru dengan menyentuh hampir semua aspek kehidupan. Teknologi telah memberi kemudahan bagi masyarakat untuk melakukan aktivitas sehari-hari dalam memenuhi kebutuhannya, serta memudahkan interaksi antar sesama manusia di mana pun berada. Penelitian ini merupakan penelitian yuridis normatif yang menggunakan pendekatan studi studi kepustakaan dan studi lapangan. Alat pengumpulan data yang digunakan dalam penelitian ini menggunakan metode wawancara dengan Wawancara dilakukan terhadap Informan atau Penyidik di Kepolisian Resor Tebing Tinggi. Analisis data dilakukan secara kualitatif. Hasil penelitian menunjukkan bahwa peran kepolisian dalam penegakan hukum terhadap tindak pidana ujaran kebencian di media sosial sebagaimana diatur dalam dalam UU No. 19 Tahun 2016 tentang Perubahan Atas UU No. 11 Tahun 2008 Tentang Informasi dan Transaksi Elektronik (UU ITE) dan Undang-Undang No. 2 Tahun 2002 tentang Kepolisian Negara Republik Indonesia. Peran kepolisian diantaranya menerima laporan atau pengaduan tentang terjadinya suatu peristiwa yang patut diduga merupakan tindak pidana wajib segera melakukan tindakan penyelidikan yang diperlukan; Sebagai penyidik yang mengetahui, menerima laporan atau pengaduan tentang terjadinya suatu peristiwa yang patut diduga merupakan tindak pidana wajib segera melakukan tindakan penyidikan yang diperlukan serta menemukan dan mengumpulkan bukti - bukti agar kasus itu menjadi terang sehingga dapat menemukan tersangkanya.

Kata Kunci: Kepolisian; Penegakan Hukum; Ujaran Kebencian; Media Sosial
\end{abstract}

\begin{abstract}
The presence of such sophisticated information technology has given a new nuance by touching almost all aspects of life. Technology has made it easy for people to carry out daily activities to meet their needs, as well as facilitate interaction between human beings wherever they are. This research is a normative juridical research that uses a literature study and field study approach. The data collection tool used in this study used the interview method. Interviews were conducted on informants or investigators at the Tebing Tinggi Resort Police. Data analysis was carried out qualitatively. The results of the study indicate that the role of the police in law enforcement against hate speech crimes on social media as regulated in Law no. 19 of 2016 concerning Amendments to Law No. 11 of 2008 concerning Information and Electronic Transactions (UU ITE) and Law no. 2 of 2002 concerning the Indonesian National Police. The role of the police includes receiving reports or complaints about the occurrence of an event that is reasonably suspected of being a criminal act; it is obliged to immediately carry out the necessary investigative actions; As an investigator who knows, receives a report or complaint about the occurrence of an event that is reasonably suspected to be a criminal act, he is obliged to immediately carry out the necessary investigative actions and find and collect evidence so that the case becomes clear so that the suspect can be found.
\end{abstract}

Keywords: Police; Law enforcement; Hate Speech; Social media

How to Cite: Samosir, R.E. Siregar, T, \& Zulyadi, R. (2021). Peranan Kepolisian Resor Tebing Tinggi Dalam Penegakan Hukum Terhadap Tindak Pidana Ujaran Kebencian Di Media Sosial. Journal of Education, Humaniora and Social Sciences (JEHSS). 4(2): 905-912. 
Renal Eldinata Samosir, Taufik Siregar, \& Rizkan Zulyadi, Peranan Kepolisian Resor Tebing Tinggi Dalam

Penegakan Hukum Terhadap Tindak Pidana Ujaran Kebencian Di Media Sosial

\section{PENDAHULUAN}

Teknologi informasi dan komunikasi telah memberikan kemudahan bagi kehidupan masyarakat dalam melakukan aktivitas sehari-hari dalam memenuhi kebutuhannya, serta memudahkan interaksi antar sesama manusia dimana pun berada. Perkembangan teknologi tidak hanya memberikan dampak positif, tetapi juga memiliki dampak negatif dengan digunakannya teknologi tersebut untuk melakukan tindak kejahatan. Perkembangan teknologi juga menyebabkan semakin banyaknya terjadi tindak kejahatan dengan modus operandi yang semaking canggih dan sulit untuk dikendalikan.

Salah satu tindak pidana yang terjadi ditengah masyarakat dengan penggunaan teknologi informasi dan komunikasi adalah ujaran kebencian dengan menggunakan media sosial. Ujaran kebencian di media sosial sering ditujukan untuk pribadi dengan menciptakan rasa permusuhan baik antar individu maupun kelompok dalam bentuk SARA agar mempengaruhi terpilihanya seseorang dalam menduduki jabatan. Selain itu ujaran kebencian juga sering ditujukan disebabkan hanya karena tindakan emosional terhadap individu maupun kelompok tertentu tanpa adanya keuntungan diperoleh. (WIBOWO et al., 2019)

Ujaran kebencian (hate speech) diartikan sebagai perkataan, tulisan, tindakan, atau pertunjukan yang ditujukan untuk menghasut kekerasan atau prasangka terhadap seseorang atas dasar karakteristik kelompok tertentu, seperti kelompok ras, etnis, gender, orientasi seksual, agama, dan lain-lain (Azhar \& Soponyono, 2020). Ujaran kebencian merupakan tindakan komunikasi yang dilakukan oleh suatu individu atau kelompok dalam bentuk provokasi, hasutan, ataupun hinaan kepada individu atau kelompok yang lain yang biasanya berbau SARA (Kamalludin \& Arief, 2019). Pidana terhadap ujaran kebencian dilakukan karena tindakan itu bisa berdampak pada tindak diskriminasi, kekerasan, penghilangan nyawa, dan atau konflik social. Adapun tindakan-tindakan yang dapat digolongkan dapat menimbulkan rasa kebencian atau permusuhan individu atau kelompok adalah: pertama menyatakan perasaan permusuhan, kebencian atau penghinaan terhadap satu atau beberapa golongan rakyat Indonesia (Ryanto, 2015). Golongan dalam hal ini dimaksudkan seluruh rakyat Indonesia dilihat dari ras, negeri asal, agama, tempat, asal, keturunan, kebangsaan atau kedudukan menurut hukum tata negara. Kedua, mengeluarkan perasaan atau melakukan perbuatan yang bersifat permusuhan, penyalahgunaan atau penodaan agama, dan menghasut orang agar tidak menganut agama apapun (Royani, 2019).

Tingkat keberhasilan pengungkapan pelaku kejahatan penyebaran ujaran melalui media sosial masih sangat rendah. Selain itu kejahatan ini semakin canggih dan rumit, sehingga menyebabkan sulit dalam melakukan penegakan hukum. (Wahyuni dkk, 2020; Jaya dkk, 2020). Kasus ujaran kebencian yang terjadi di Indonesia dapat dilihat pada Kasus Dedi Antoni Barus Als Dedi Karo yang melakukan ujaran kebencian di media sosial facebook. (Manalu, 2019; Palindungan, 2019). Ujaran Kebencian (Hate Speech) yang dilakukan Dedi Antoni Barus berupa membuat postingan dengan kata-kata bertuliskan: Allah fuck you ga adil semua itu, Hahaha jelen sujud sapa siapa tuhan kelen itu tanda jempol kebawah tanda + tanda jempol keatas tanda telunjuk keatas, Allah anjeng, Islam itu tanda jempol kebawah dan Islam itu Babi. Maksud dan tujuannya membuat postingan tersebut adalah agar Viona Damanik merasa sakit hati dan tidak ada orang lain yang mengarahkan, membimbing ataupun mengajarinya untuk membuat postingan tersebut. Pelaku menulis postingan status tersebut pada tanggal 12 Oktober 2017. Dengan demikian Dedi Antoni Barus telah terbukti melakukan perbuatan "dengan sengaja dan tanpa hak menyebarkan informasi yang ditujukan untuk menimbulkan rasa kebencian atau permusuhan individu dan/atau kelompok masyarakat tertentu berdasarkan atas suku, agama, ras, dan antar golongan (SARA)“ yang dilakukan dengan cara memposting tulisan yang menghina agama islam, diancam dengan pidana penjara paling lama 6 (enam) tahun dan/atau denda paling banyak Rp 1.000.000.000,00 (satu miliar rupiah) sebagaimana dimaksud dalam Pasal 45 A ayat (2) UU RI No. 19 Tahun 2016 tentang perubahan atas UU RI No. 11 tahun 008 tentang Informasi dan Transaksi Elektronik. (Resume Perkara di Polres Tebing Tinggi:2018) Tetapi kasus tersebut pelakunya anak di bawah umur dan 
berdamai dengan korban. Polres Tebing Tinggi telah mengupayakan restorative justice karena pelakunya adalah anak di bawah umur, dan hasilnya berhasil sehingga kasus dapat di SP3 kan.

Kepolisian Resor Tebing Tinggi sebagai institusi penegak hukum mempunyai peran yang sangat besar dalam penegakan hukum, khususnya penegakan hukum terhadap tindak pidana ujaran kebencian melalui media sosial, yang biasanya ditangani oleh unit Tipidter (tindak pidana tertentu). Dalam sistem peradilan pidana, kepolisian merupakan institusi pertama yang melakukan penanganan terhadap semua tindak pidana dengan cara melakukan penyidikan, sehingga dapat dikatakan bahwa keberhasilan penegakan hukum terhadap tindak pidana ujaran kebencian melalui media sosial sangat tergantung pada hasil kerja kepolisian. (Ferra dkk, 2019).

\section{METODE PENELITIAN}

Penelitian Peranan Kepolisian Resor Tebing Tinggi Dalam Penegakan Hukum Terhadap Tindak Pidana Ujaran Kebencian Di Media Sosial merupakan penelitian yuridis normatif. Penelitian hukum normatif bertujuan untuk meneliti bahan hukum perpustakaan. Sumber bahan hukum dalan penelitian ini yatu sebagai berikut: a) Bahan hukum primer yang merupakan norma/peraturan dasar dan peraturan perundang - undangan yang berhubungan dengan penegakan hukum tindak pidana ujaran kebencian di media social; b) Bahan hukum sekunder merupakan bahan hukum yang bersifat membantu atau menunjang bahan hukum primer dalam penelitian yang akan memperkuat penjelasan di dalamnya. Bahan hukum yang memberikan penjelasan mengenai bahan hukum primer, yang terdiri dari literatur-literatur, buku-buku yang berkaitan dengan penegakan hukum tindak pidana ujaran kebencian di media sosial; c) Bahan hukum tersier yaitu bahan yang memberi petunjuk dan penjelasan terhadap bahan hukum primer dan bahan sekunder seperti kamus umum, kamus hukum, ensiklopedia, dan lain sebagainya. Nomensen Sinamo:2010)

Alat pengumpulan data yang digunakan dalam penelitian ini yakni dalam hal mengumpulkan data primer dengan menggunakan metode wawancara dengan Wawancara dilakukan terhadap Informan atau Penyidik di Kepolisian Resor Tebing Tinggi. Jenis wawancara yang digunakan adalah wawancara tidak terstruktur atau bebas, dimana peneliti tidak berpedoman pada wawancara yang terstruktur sistematis lengkap untuk pengumpulan datanya. Analisis data merupakan langkah terakhir dalam suatu kegiatan penulisan. Analisis data dilakukan secara kualitatif yaitu penelitian tentang riset yang bersifat deskriptif dan cenderung menggunakan analisis, proses dan makna yang lebih diutamakan (Soekanto; 2015). Dalam penelitian kualitatif landasan teori dimanfaatkan sebagai pemandu agar fokus penelitian sesuai dengan fakta di lapangan. (Nomensen Sinamo:2010) Data yang diperoleh melalui pengumpulan data sekunder akan dikumpulkan dan kemudian dianalisis dengan cara kualitatif untuk mendapatkan kejelasan terhadap masalah yang akan dibahas. (Burhan:2008) Semua data yang terkumpul diedit, diolah dan disususn secara sistematis untuk selanjutnya disimpulkan dengan menggunakan metode deduktif umum ke khusus, yaitu proses penalaran dari satu atau lebih pernyataan umum untuk mencapai kesimpulan.

\section{HASIL DAN PEMBAHASAN}

\section{Aturan Hukum Mengenai Tindak Pidana Ujaran Kebencian di Media Sosial.}

Beberapa aturan hukum yang mengatur tenang tindak pidana ujaran kebencian di media sosial diantaranya:

a) Undang - Undang Nomor 11 Tahun 2008 tentang Informasi dan Transaksi Elektronik.

Bentuk pertanggung jawaban pidana terhadap pelaku tindakpidana ujaran kebencian di media sosial berdasarkan asas lexspecialis derogat legi generali mengacu kepada ketentuan Pasal 28 ayat (2) jis. Pasal 45A ayat (2) Undang-Undang Republik IndonesiaNomor 19 Tahun 2016 Tentang Perubahan Atas Undang-Undang Nomor 11 Tahun 2008 Tentang Informasi Dan Transaksi Elektronik. Unsur-unsur tindak pidana ITE dalam Pasal 28 ayat (2) yaitu: 1) 
Kesalahan: dengan sengaja; 2) Melawan hukum: tanpa hak; 3) Perbuatan: menyebarkan; 4) Objek: Informasi; 5) Tujuan: untuk menimbulkan rasa kebencian atau permusuhan individu dan/atau kelompok masyarakat tertentu berdasarkan atas suku, agama, ras, dan antargolongan (SARA). (Adami Chazawi :2011)

Dengan adanya pertanggung jawaban pidana terhadap orang yang terbukti memenuhi unsur-unsur tindak pidana dalam Pasal 28 ayat (2) ITE berdasarkan Pasal 45A ayat (2) ITE adalah pidana penjara maksimal 6 tahun dan/atau pidana denda paling banyakRp1.000.000.000,00 (satu miliar rupiah).

b) Surat Edaran Kapolri NomorSE/06/X/2015 tentang Ujaran Kebencian (Hate Speech).

Berdasarkan Surat Edaran Kapolri Nomor SE/06/X/2015 tentang Ujaran Kebencian (Hate Speech) disebutkan tentang Ujaran Kebencian (Hate Speech) dapat berupa tindak pidana yang di atur dalam KUHP dan ketentuan-ketentuan pidana lainnya di luar KUHP, yang berbentuk: 1) Penghinaan; 2) Pencemaran nama baik; 3) Penistaan; 4) Perbuatan tidak menyenangkan; 5) Memprovokasi; 6) Menghasut; 7) Menyebarkan berita bohong.

Tindakan yang disebut di atas memiliki dampak akan terjadinya penghilangan nyawa, kekerasan, diskriminasi, atau konflik sosial (Chairul: 2005). Tujuan dari ujaran kebencian sebagaimana yang disebutkan di atas adalah untuk menghasut dan menyulu tkebencian terhadap individu dan/atau kelompok masyarakat dalam berbagai komunitas. Dalam huruf (h) Surat Edaran tersebut, Ujaran Kebencian (Hate Speech) dapat dilakukan melalui berbagai media, antara lain: 1) Dalam orasi kegiatan kampanye; 2) Spanduk atau banner; 3) Jejaring media social; 4) Penyampaian pendapat di muka umum (demonstrasi); 5) Ceramah keagamaan; 6) Media masa cetak atau elektronik; 7) Pamflet.(Anam \& Hafiz, 2015)

Penegakan hukum atas dugaan terjadinya tindak pidana ujaran kebencian berdasarkan Surat Edaran Kapolri NomorSE/06/X/2015 tentang Ujaran Kebencian (Hate Speech) mengacu pada ketentuan: 1) Pasal 156 KUHP; 2) Pasal 157 KUHP; 3) Pasal 310 KUHP; 4) Pasal 311 KUHP; 5) Pasal 28 ayat (2) jo. Pasal 45 ayat (2) UU Nomor 11 Tahun 2008 tentang Informasi dan Transaksi Elektronik; 6) Pasal 16 UU Nomor 40 Tahun 2008 tentang Penghapusan Diskriminasi Ras dan Etnis

\section{Peranan Kepolisian Resor Tebing Tinggi Dalam Penegakan Hukum Terhadap Tindak Pidana Ujaran Kebencian}

Tugas polisi secara umum sebagaimana tercantum dalam Pasal 13 Undang-Undang No. 2 Tahun 2002 tentang Kepolisian Negara Republik Indonesia, menyebutkan bahwa tugas pokok Kepolisian Negara Republik Indonesia adalah: Memberikan keamanan dan ketertiban masyarakat; Menegakkan hukum; Memberika perlindungan, pengayoman, dan pelayanan kepada masyarakat (Pasal 13 Undang-Undang No. 2 Tahun 2002 tentang Kepolisian Negara Republik Indonesia) (Pandelaki, 2018)

Untuk mendukung tugas pokok tersebut di atas, polisi juga memiliki tugas-tugas tertentu sebagaimana tercantum dalam Pasal 14 ayat (1) Undang-Undang No. 2 Tahun 2002 tentang Kepolisian Negara Republik Indonesia adalah sebagai berikut:(Puspitasari \& Devintawati, 2018) Melaksanakan pengaturan penjagaan, pengawalan, dan patrol terhadap kegiatan masyarakat dan pemerintah sesuai kebutuhan; Menyelenggarakan segala kegiatan dalam menjamin keamanan, ketertiban dan kelancaran lalu lintas di jalan; Membina masyarakat untuk meningkatkan partisipasi masyarakat, kesadaran hukum masyarakat, serta ketaatan warga masyarakat terhadap hukum dan peraturan perundang-undangan; Turut serta dalam pembinaan hukum nasional; Memelihara ketertiban dan menjamin keamanan umum : melakukan koordinasi, pengawasan, dan pembinaan teknis terhadap kepolisian khusus, penyidik pegawai negeri sipildan bentuk- bentuk pengamanan swakarsa; Melakukan koordinasi, pengawasan, dan pembinaan teknis terhadap kepolisian khusus, penyidik pegawai negeri sipil dan bentukbentuk pengamanan swakarsa; Melakukan penyelidikan terhadap semua tindak pidana sesuai dengan hukum acara pidana dan peraturan perundang-undangan lainnya; Menyelenggarakan identifikasi kepolisian, kedokteran kepolisian, laboratorium forensik dan psikologi kepolisian untuk kepentingan tugas kepolisian; Melindungi keselamatan jiwa raga, harta benda, 9.0. $\mathrm{http}: / /$ mahesainstitute.web.id/ojs2/index.php/jehss Nahesainstitut@gmail.com 908 
masyarakat dan lingkungan hidup dari gangguan ketertiban dan / atau bencana termasuk memberikan bantuan dan pertolongan dengan menjunjung tinggi hak asasi manusia; Melayani kepentingan warga masyarakat untuk sementara sebelum ditangani oleh instansi/ atau pihak berwenang; Memberikan pelayanan kepada masyarakat sesuai dengan kepentingan dalam lingkup tugas kepolisian; Melaksanakan tugas lain sesuai dengan peraturan perundangundangan (Pasal 14 ayat (1) Undang-Undang No. 2 Tahun 2002 tentang Kepolisian Negara Republik Indonesia)

Menurut hasil wawancara penulis dengan Bapak AKP. Wirhan Arif, Sh, SIK,MH selaku Kasat Reskrim Polres Tebing Tinggi Peran Kepolisian dalam penegakan hukum tindak pidana ujaran kebencian yaitu: Sebagai penyelidik yang mengetahui, menerima laporan atau pengaduan tentang terjadinya suatu peristiwa yang patut diduga merupakan tindak pidana wajib segera melakukan tindakan penyelidikan yang diperlukan; Sebagai penyidik yang mengetahui, menerima laporan atau pengaduan tentang terjadinya suatu peristiwa yang patut diduga merupakan tindak pidana wajib segera melakukan tindakan penyidikan yang diperlukan (Pasal 106 Undang-Undang No. 8 Tahun 1981 tentang Kitab Undang-Undang Hukum Acara Pidana). Penyidikan merupakan upaya dalam menemukan dan mengumpulkan bukti-bukti untuk menjadikan kasus itu menjadi terang sehingga dapat menemukan tersangkanya. Adapun rangkaian penyidikan yang dilakukan oleh Polisi diantaranya penangkapan, penahanan, penggeledahan, penyitaan (Topo:2012).

\section{Kendala Yang Dihadapi Kepolisian Resor Tebing Tinggi Dalam Penegakan Hukum Terhadap Tindak Pidana Ujaran Kebencian Di Media Sosial.}

Masih banyaknya anggota masyarakat yang melakukan tindak pidana ujaran kebencian, baik terhadap perorangan maupun terhadap kelompok atau golongan (Wijayanto, 2017). Hal ini dikarenakan masih kurangnya peran kepolisian dalam penegakan hukum ujaran kebencian disebabkan kepolisian menghadapi sejumlah kendala, yaitu: pelakunya tokoh masyarakat, dianggap mengekang kebebasan berpendapat, SIM Card dapat digunakan tanpa proses registrasi, kurangnya kesadaran masyarakat atas larangan penyebaran ujaran kebencian, serta beredarnya akun palsu. Masing-masing kendala dan upaya untuk mengatasi kendala tersebut dapat dijelaskan sebagai berikut:

a) Pelakunya Tokoh Masyarakat.

Substansi Beberapa tokoh masyarakat yang dianggap menjadi panutan di tengah masyarakat kadang terlibat sebagai pelaku ujaran kebencian, sehingga menyulitkan dalam penyidikan. Tokoh tersebut dapat berupa tokoh agama atau tokoh politik sehingga memiliki basis massa sebagaimana dinyatakan dalam wawancara berikut:

Menurut AKP Wirhan Arif, SH, S.I.K, MH selaku Kasat Reskrim Polres Tebing Tinggi: "Keterlibatan tokoh masyarakat sebagai pelaku ujaran kebencian tentu sangat meresahkan, karena penindakan terhadap orang tersebut dapat menimbulkan gejolak sosial di masyarakat. Artinya bahwa jika tokoh masyarakat terlibat sebagai pelaku dalam penyebaran ujaran kebencian, maka penegakan hukum akan mengalami kendala yang relative besar, karena pemidanaan atau proses hukum terhadap tokoh masyarakat tersebut dapat memicu pendukungnya untuk melakukan unjuk rasa sehingga menimbulkan gejolak sosial di tengah masyarakat.

b) Dianggap Mengekang Kebebasan Berpendapat.

Di negara demokrasi sebagaimana juga di Indonesia, masyarakat memiliki kebebasan untuk menyatakan pendapat, sehingga setiap adanya tindakan kepada pelaku yang mengungkapkan pendapatnya di media sosial dianggap sebagai mengekang kebebasan berpendapat, sebagaimana dinyatakan dalam wawancara berikut:

Menurut AKP Wirhan Arif, SH, S.I.K, MH selaku Kasat Reskrim Polres Tebing Tinggi: Banyak pihak yang menganggap bahwa pidana terhadap penyebaran kebencian sebagai upaya pengekangan terhadap kebebasan berpendapat di masyarakat, padahal hal tersebut sangat 
Renal Eldinata Samosir, Taufik Siregar, \& Rizkan Zulyadi, Peranan Kepolisian Resor Tebing Tinggi Dalam

Penegakan Hukum Terhadap Tindak Pidana Ujaran Kebencian Di Media Sosial

meresahkan bagi orang lain. Artinya bahwa masih ada pihak tertentu di masyarakat yang menganggap pengungkapan rasa tidak suka kepada orang lain atau kelompok lain bukan merupakan tindakan criminal, karena setiap anggota masyarakat seharusnya bebas dan mempunyai hak untuk mengeluarkan atau menyatakan pendapat sesuai dengan akal pikirannya, padahal hal tersebut jelas telah melanggar hak orang lain.

c) Sim Card Tanpa Registrasi Pengguna. Pada saat ini anggota masyarakat dapat membeli dan menggunakan SIM Card secara bebas tanpa melalui proses registrasi, sehingga akun yang dibuat dari SIM Card tersebut sulit untuk dilacak, sebagaimana dinyatakan dalam wawancara berikut: Menurut AKP Wirhan Arif, SH, S.I.K, MH selaku Kasat Reskrim Polres Tebing Tinggi: Orang-orang dapat memperoleh SIM Card tanpa melalui proses registrasi, sehingga orang tersebut tidak terdaftar sebagai pengguna SIM Card yang dimaksud, dan menyulitkan penyidik untuk melakukan pelacakan. Artinya bahwa SIM Card yang tidak terdaftar atas nama pengguna sudah banyak beredar di masyarakat, karena SIM Card sudah dapat digunakan tanpa proses registrasi. Jika SIM Card tersebut digunakan untuk melakukan tindak pidana, seperti tindak pidana penyebaran kebencian, maka akan sangat sulit untuk melancak siapa yang memposting ujaran kebencian tersebut.

d) Kurangnya Kesadaran Masyarakat terhadap Larangan Penyebaran Kebencian. Kesadaran masyarakat terhadap hukum masih tergolong kurang memadai, khususnya terhadap hukum larangan penyebaran kebencian. masih banyak anggota masyarakat yang tidak memahami secara benar tentang larangan penyebaran kebencian melalui media sosial, atau bahkan masih banyak yang tidak mengetahui adanya larangan tersebut. Hal ini menyebabkan orang tersebut merasa bebas mengungkapkan dan menyebarkan rasa tidak sukanya terhadap orang tertentu melalui media sosial, tanpa menyadari bahwa tindakannya tersebut telah dinyatakan merupakan pelanggaran terhadap peraturan hukum yang berlaku.

Oleh karena itu untuk mengatasi kendala tersebut perlu dilakukan sosialisasi yang gencar kepada masyarakat mengenai UU ITE, khususnya mengenai larangan penyebaran kebencian sebagaimana dinyatakan dalam wawancara berikut: Menurut AKP Josua Nainggolan selaku Kasubbag Humas Polres Tebing Tinggi: Sosialisasi larangan penyebaran kebencian kepada masyarakat perlu dilakukan dengan gencar, sehingga masyarakat memahami adanya larangan tersebut serta sanksi hukum atas setiap pelanggaran yang dilakukan.

Artinya jelas bahwa selama ini sosialisasi UU ITE masih kurang dilaksanakan, sehingga kesadaran masyarakat juga masih kurang, yang berdampak pada maraknya tindak pidana ujaran kebencian di tengah masyarakat. Untuk mengatasi masalah tersebut maka sebaiknya dilakukan sosialisasi yang gencar kepada masyarakat agar sadar hukum dan tidak sembarangan menyebarkan kata-kata yang bersifat permusuhan dengan orang atau golongan tertentu. Sosialisasi tersebut dapat dilakukan dengan pengarahan secara langsung kepada anggota masyarakat, atau dapat juga dilakukan dalam bentuk tulisan berupa spanduk atau pesan-pesan di media elektronik.

e) Adanya Akun Palsu. Akun palsu menjadi hal yang cukup meresahkan dalam penggunaan media sosial. Walaupun tidak semua akun palsu melakukan tindak pidana, tetapi banyak juga diantaranya dibuat secara sengaja untuk tujuan penyebaran ujaran kebencian sebagaimana dinyatakan dalam wawancara berikut: Menurut AKP Wirhan Arif, SH, S.I.K, MH selaku Kasat Reskrim Polres Tebing Tinggi: Keberadaan akun palsu, baik di fasebook maupun twitter tentu sangat berpotensi digunakan sebagai alat penyebaran kebencian, tetapi karena akunnya palsu, maka keberadaannya sulit untuk dilacak.

Artinya bahwa pelaku penyebaran ujaran kebencian tidak dapat dilacak jika menggunakan akun palsu. Hal ini tentu sangat meresahkan karena akun palsu yang banyak beredar sangat berpotensi digunakan untuk menyebarkan ujaran kebencian. Pada sisi lain, akun palsu tergolong mudah dibuat dengan memalsukan semua identitas penggunanya, sebagaimana dinyatakan dalam wawancara berikut: Menurut IPDA Eben Ezer Tarigan selaku Kanit Tipidter Polres Tebing Tinggi: Akun palsu mudah dibuat dengan data profil yang sebagian besar dipalsukan, bahkan foto diripun dapat dipalsukan. Infomasi yang disebarkan oleh akun tersebut juga cenderung menyesatkan. 
Artinya kemudahan membuat akun palsu menjadi hal yang berbahaya karena hampir semua data diri (profil) di dalam akun palsu dapat dimanipulasi hingga foto diri penggunanya. Akun palsu tersebut juga cenderung digunakan untuk menyebarkan berita yang menyesatkan. Cara efektif untuk mengatasi akun palsu seharusnya adalah dengan memperketat syarat membuat akun media sosial sebagaimana dinyatakan dalam wawancara berikut: Menurut AKP Josua Nainggolan selaku Kasubbag Humas Polres Tebing Tinggi: Kepolisian telah menonaktifkan atau melakukan take down banyak akun palsu, tetapi hal tersebut tidak efektif karena akun palsu yang lain akan mundah muncul. Cara efektif adalah memperketat persyaratan untuk membuat akun media sosial, dengan tidak dapat membuat identitas palsu. Artinya bahwa walaupun kepolisian dapat melakukan take down terhadap akun palsu, tetapi cara tersebut tidak efektif untuk menanggulagi beredarnya akun palsu, karena dalam waktu yang sama justru dapat muncul akun palsu baru di media sosial. Cara yang paling efektif untuk menanggulangi akun palsu seharusnya adalah dengan memperketat pembuatan akun palsu, dengan benar-benar harus mencantumkan data diri asli pengguna atau pemiliknya. Dengan demikian pembuat akun palsu tersebut tidak mudah terdorong atau akan lebih hatihati dalam menyebarkan informasi, karena keberadaannya mudah dilacak oleh kepolisian.

\section{SIMPULAN}

Aturan hukum tentang ujaran kebencian melalui media sosial diatur dalam UU No. 19 Tahun 2016 tentang Perubahan Atas UU No. 11 Tahun 2008 Tentang Informasi dan Transaksi Elektronik (UU ITE). Pada Pasal 28 ayat (2) UU ITE dinyatakan bnahwa: Setiap orang dengan sengaja dan tanpa hak menyebarkan informasi yang ditujukan untuk menimbulkan rasa kebencian atau permusuhan individu dan/atau kelompok masyarakat tertentu berdasarkan atas suku, agama, ras, dan antargolongan (SARA). Sedangkan ancaman pidana diatur dalam pasal 45 ayat (2) adalah dipidana dengan pidana penjara paling lama 6 (enam) tahun dan/atau denda paling banyak Rp. 1.000.000.000,00 (satu miliar rupiah). Penegakan hukum terhadap tindak pidana ujaran kebencian diawali dengan menerima laporan dari masyarakat, kemudian dilanjutkan dengan analisis bukti fisik seperti print screen shot, handphone, Ipad, dan notebook, serta meminta keterangan saksisaksi, termasuk juga saksi ahli. Keterangan saksi ahli dalam penyidikan ujaran kebencian adalah sangat penting karena dapat menganalisis keaslian dari alat-alat bukti sebagai ahli forensic digital ,serta dapat menganalisis makna yang terkandung dalam ujaran kebencian sebagai ahli bahasa. Jika alat bukti meyakinkan mengarah pada terlapor maka penyidik akan memanggil terlapor untuk dimintai ketrangannya, yang berdasarkan pemeriksaaan dapat ditetapkan statusnya sebagai tersangka. Selanjutnya, berkas perkara yang telah dinyatakan lengkap akan dilimpahkan ke jaksa penuntut umum bersama dengan tersangka. Faktor kendala yang dihadapi dalam penegakan hukum terhadap penyebaran ujaran kebencian melalui media sosial adalah: pelakunya adalah tokoh masyarakat, dianggap mengekang kebebasan berpendapat, SIM Card dapat digunakan tanpa proses registrasi, kurangnya kesadaran masyarakat atas larangan penyebaran ujaran kebencian, serta beredarnya akun palsu. Tokoh masyarakat dianggap sebagai panutan di tengah masyarakat dan memiliki basis massa, sehingga dapat menimbulkan gejolak sosial jika ditindak sesuai dengan proses hukum. Sebagian kalangan menganggap bahwa pemidanaan terhadap penyebar kebencian merupakan pengekangan terhadap kebebasan berpendapat. SIM Card telah dapat digunakan tanpa proses registrasi sehingga kepolisian kesulitan melakukan penelusuran untuk mencari tersangkanya karena akun yang digunakan tidak dapat diidentifikasi kepada identitas penggunanya. Masih banyak anggota masyarakat yang tidak mengetahui adanya larangan penyebaran ujaran kebencian sehingga tidak hati-hati untuk memposting kata-kata yang menghujat bagi pihak lain atau bahkan menghujat pejabat pemerintah. Akun palsu tidak mudah dilacak kepolisian karena hamper semua identitas pemiliknya adalah palsu, padahal sering digunakan untuk menyebarkan informasi kebencian.

\section{DAFTAR PUSTAKA}


Renal Eldinata Samosir, Taufik Siregar, \& Rizkan Zulyadi, Peranan Kepolisian Resor Tebing Tinggi Dalam

Penegakan Hukum Terhadap Tindak Pidana Ujaran Kebencian Di Media Sosial

Anam, M. C., \& Hafiz, M. (2015). Surat Edaran Kapolri Tentang Penanganan Ujaran Kebencian (Hate Speech) dalam Kerangka Hak Asasi Manusia. Jurnal Keamanan Nasional, 1(3), 341-364.

Ashshofa, Burhan, 2008, Metode Penelitian Hukum, Rineka Cipta, Jakarta

Azhar, A. F., \& Soponyono, E. (2020). Kebijakan Hukum Pidana dalam Pengaturan dan Penanggulangan Ujaran Kebencian (Hate Speech) di Media Sosial. Jurnal Pembangunan Hukum Indonesia, 2(2), 275290.

Ferra, F., Tanoto, S., \& Lifia, M. (2019). Penegakan Hukum terhadap Pelaku Tindak Pidana Korupsi dan Perhitungan Kerugian Keuangan Negara Berdasarkan Undang-undang Nomor 31 Tahun 1999 tentang $\begin{array}{llll}\text { Tindak Pidana Korupsi. JURNAL } & \text { MERCATORIA, } & 12(2), & 139-147 .\end{array}$ doi:https://doi.org/10.31289/mercatoria.v12i2.2755

Huda, Chairul, 2005, Dari Tiada Perbuatan Tanpa Kesalahan Menuju Kepada Tiada Pertanggungjawaban Pidana Tanpa Kesalahan, Kencana, Jakarta.

Jaya, A., Eddy, T., \& Sahari, A. (2020). Penegakan Hukum Pidana Terhadap Anak Yang Terjerat Perkara Pidana Melalui Diversi (Studi Di Polrestabes Medan). Journal of Education, Humaniora and Social Sciences (JEHSS), 3(1), 78-84. doi:https://doi.org/10.34007/jehss.v3i1.196

Kamalludin, I., \& Arief, B. N. (2019). Kebijakan Formulasi Hukum Pidana Tentang Penanggulangan Tindak Pidana Penyebaran Ujaran Kebencian (Hate Speech) Di Dunia Maya. Law Reform, 15(1), 113-129.

Manalu, H. S (2019). Penegakan Hukum Terhadap Pelaku Tindak Pidana Perjudian Online (Studi Putusan Pengadilan Negeri Medan Nomor 870/Pid.B/2018/PN.Mdn). Journal of Education, Humaniora and Social Sciences (JEHSS). 2 (2): 428-447.

Nomensen Sinamo, 2010, Metode Penelitian Hukum dalam Teori dan Praktek, Bumi Intitama Sejahtera, Jakarta

Pandelaki, G. R. (2018). Peran Polisi Dalam Pengendalian Massa Berdasarkan Undang-Undang Nomor 2 Tahun 2002 Tentang Kepolisian Negara Republik Indonesia. Lex Et Societatis, 6(5).

Parlindungan, A. (2019). Analisis Penegakan Hukum terhadap Tindak Pidana Politik Uang dalam Pemilihan Kepala Daerah (Pilkada) Ditinjau Dari Undang-Undang Nomor 10 Tahun 2016. Journal of Education, Humaniora and Social Sciences (JEHSS). 2 (2): 335-351.

Puspitasari, I., \& Devintawati, E. (2018). Urgensi Pengaturan Kejahatan Korporasi dalam Pertanggungjawaban Tindak Pidana Korporasi Menurut RKUHP. Kanun Jurnal Ilmu Hukum, 20(2), 237-254.

Royani, Y. M. (2019). ANALISIS PASAL 156 KUHP TENTANG UJARAN KEBENCIAN PERSPEKTIF HAK ASASI MANUSIA. At-Tawasuth, 1(1), 48-60.

Ryanto, A. (2015). Eksistensi dan Kedudukan Hukum Surat Edaran Kapolri tentang Penanganan Ujaran Kebencian (Hate Speech). Jurnal Cahaya Keadilan, 3(2), 1-13.

Santoso, Topo, 2012, Asas-Asas Hukum Pidana, Sinar Grafika, Jakarta

Soekanto, Soejono dan Sri mamudji, 2015, Penelitian Hukum Normatif suatu Tinjauan Singkat, Raja Grafindo Persada, Jakarta.

Wahyuni, F., Eddy, T., Eddy, T., Sahari, A., \& Sahari, A. (2020). Penegakan Hukum Persidangan Cepat Dalam Penyelesaian Perkara Pelanggaran Lalu Lintas (Studi Satlantas Polrestabes Medan). Journal of Education, Humaniora and Social Sciences

WIBOWO, A., Nashriana, N., \& Ikhsan, R. (2019). UPAYA KEPOLISIAN DAERAH SUMATERA SELATAN DALAM PENCEGAHAN TINDAK PIDANA UJARAN KEBENCIAN DI MEDIA SOSIAL. Sriwijaya University.

Wijayanto, D. E. (2017). Tinjauan Yuridis Ujaran Kebencian Dimedia Sosial diinjau dari Undang Undang No 11 Tahun 2008 tentang Informasi dan Transaksi Elektronik yang Telah Diperbarui di Dalam Undang Undang No 19 Tahun 2016 Tentang Informasi dan Transaksi Elektronik. Jurnal Independent, 5(2), 3545.

Berkas Perkara "NOMOR: BP/28/III/2018/DITTIPIDSIBER

Surat Edaran Kapolri NomorSE/06/X/2015 tentang Ujaran Kebencian (Hate Speech) 